\title{
A Look at the Public Sphere in Talk Show Programs in Albania
}

\author{
Msc. Elvin Luku (Ph. Candidate)
}

Journalist, Vizion Plus TV elvini133@yahoo.com

\section{Doi:10.5901/mjss.2013.v4n10p574}

\begin{abstract}
The aim of this paper is to analyse the daytime audience participating TV talk shows that are conceptualized as new public spheres in terms of the Massive Communication Medias. These kinds of shows with a broad variety of guests deal with different topics such as political, social, economic, etc. And these topics concern the broad public opinion. In the study we will focus on this kind of talk show format in Albania. The research aims at tackling this public sphere created by televisions as well as the involvement of various social groups in the public debate. It analyses not only the involvement that this formats give to the public in the studio but also to the viewers at home, who are active in the social networks. This study is based on the theory of the German philosopher Jürgen Habermas on the public sphere, the transformation and the evolvement of this concept nowdays. We will try to give an answer to the concern of this critical theorist of the Frankfurt School about the creation or not of a new bourgeois class, which rules this mediatic public sphere, and how this is reflected on TV Talk Show in Albania.Besides the theoretical approach of daytime talk shows by the contemporary authors of communication like Bernard Timbering, Sonia Livingstone, Horace Newcomb, Pierre Bourdieu, Jürgen Habermas, this study will also analyse certain daytime talk shows with an audience participating in Albania.
\end{abstract}

Keywords: Talk show, public sphere, participating democracy, moderator, audience, advertisement, television

\section{Introduction}

By just zapping through the main TV channels in Albania you can ascertain that the four classic genres of talk shows exist (Luku, 2013, p. 185). However, problems are obvious.

What you immediately notice is that there is an abundance of political talk shows (Luku, EJO, 2013) where we can mention talk shows such as Opinion, Top Story, $360^{\circ}$, Tonight, Prizëm, Fakt, Zonë e Ndaluar, Shqip, Bugajski Hour, etc. Discussions are dominated by the same debaters. They go from one studio to another, maintain their attitudes and get involved in the same conflicts (Vehbiu, 2009).

Talk shows in Albania are a "déjà vu"!

As a second element you can notice a lack of involvement of the public in the studio during the discussion (Vehbiu, 2011). This is especially noticed in daytime audience-participating talk shows, like Pasdite në Top Channel, Emisioni $i$ pasdites apo Ora $5 \mathrm{pm}$, etc. In the best of cases the public is seen as just spectators. It is present just to applaud and this, when it is asked to do so.

There are also, programs of this genre where there is no public at all in the studio. The same problem can be noticed even in the other kinds of talk shows in Albania.

In the last years, with an increase in the number of social network users, a part of the shows have integrated the online community, even though it is bias only from the public in the studio and not vice-versa.

There can be noticed only a small number of satirical shows, among which the most prominent are Fisk Fare are By Pass Show. This kind of format is included in the late-night entertainment talk show. In this category are also included other formats such as A Show, Top Show, Natën me Xhaxhiun and Natën Vonë, sporting programs like Dribbling and Skaner Kampionat, even though these programs are more focused on the talk and lack the entertaining element. In this genre are included the Talk show Procesi Sportiv, which has a combination between sport information and humor, and the infotainment program Zonë e Lirë (Luku, 2010, p. 335).

As far as morning talk shows are concerned, we can notice radio-television programs like Wake Up, Klubi $i$ Mëngjesit, Aldo morning show, Koha për t'u zgjuar as well as the morning magazine-format talk show, ZIP. 


\subsection{Theoretic approach on the talk show as a public sphere}

From the above outlook, the problems highlighted can be summarized in the so-called relation between quality and audience. This debate has its roots in the ideological separation between the Left and the Right Wing. There is a difference between an elite democracy where communication between established power and the laity takes the form of dissemination from the powerful and the representation of ordinary beliefs as mass opinion, and a participatory democracy where established power is engaged in some kind of dialogue with the public.

Both the left and right of the political spectrum are concerned with the individual as citizen, and with undermining the authority of the expert or elite. The right attacks experts for their abstract, biased or ungrounded authority over the laity. They argue for reductions in restrictions on broadcasting to encourage competition according to market forces and audience demand, thereby putting pressure on the existing broadcast channels to become more accessible and populist. The left has also been concerned with the rights of individuals and the validity of everyday experience (Livingstone \& Lunt, 1994, p. 9).

Talk show programs, especially those with an audience follow this debate and try to pay attention to the public as well as to the expert. The Media as a great power of the society, aims at getting involved in political events and to play an important role in the political decision-making.

Presently, the contemporary media debate is focused on the concept of "public sphere" and on the space that televisions or newspapers dedicate to the "citizen" as the main actor inside this sphere. Researchers emphasize that if the citizen is going to play a role in the democracy, then he has to participate in these institutionally guaranteed forums where he can express his opinions and his concerns about the political power.

The question that rises is, do these talk shows in Albania guarantee these free public forums?

Before we answer this question, we must first clarify the term "public sphere". The author who has elaborated this concept is Jürgen Habermas, a thinker of the Frankfurt school, who says that:

By "the public sphere" we mean first of all a realm of our social life in which something approaching public opinion can be formed. Access is guaranteed to all citizens. A portion of the public sphere comes into being in every conversation in which private individuals assemble to form a public body. They then behave neither like business or professional people transacting private affairs, nor like members of a constitutional order subject to the legal constrains of a state bureaucracy. Citizens behave as a public body when they confer in an unrestricted fashion - that is, with the guarantee of freedom of assembly and in association and the freedom to express and publish their opinions - about matters of general interest. In a large public body this kind of communication requires specific means for transmitting information and influencing those who receive it. Today newspaper and magazines, radio and television are the media of the public sphere (Habermas, Lennox, S \& Lennox, F., 1964, p. 2).

Habermas continues his idea by underlining the fact that the dimension of the public sphere won't be complete if the public organ that is formed, doesn't work as whole thanks to the consensus and if a rational and critical discussion isn't developed on the points at issue.

Presently, the authors of the feminist movement, among which the most prominent Nancy Fraser and Carol Gould, elaborate another concept about the public space. According to them, Habermas is wrong when he calls the public as unified, homogenous and capable of expressing itself beyond its personal interest for the common good. Fraser emphasizes that this idea is problematic because the public is "fragmented into a mass of competing interest groups" who may or may not represent fairly all sections of the general public (Fraser, 1990, p. 14).

On the fact that the public space is dominated by the rational discussion, Carol Gould states that this is a very chauvinistic approach. According to her the emotions, feelings and the passions of the debaters take a great part in public speaking (Fuga, 2013).

At a later time, Habermas accepts the plurality inside the society, but adds that the public can be capable of debating with the established power, only when thanks to the consensus it settles the differences among the social groups.

When speaking of the economic power and the media, which he defines as the "industry of culture", Habermas points out that their penetration into the institutional public sphere, from where the public can contradict the established power as it used to, in the bourgeoisie public sphere, has damaged the rational and critical debate. According to him, "the capturing" of the public sphere has transformed the public into a mindless mass (Habermas, 1991, p. 120).

On the other hand the authors of the feminist movement contradict Habermas by stating that this crisis comes from the imposition that the established power makes on the public through the elites, which conceive it as homogeneous mass, where the diversity of voices is excluded from the public sphere. 
Despite the opposition, Habermas argues that the public sphere exists now only as a promise. Party politics and the manipulation of the mass media have resulted in a "refeudalization" of the public sphere, where representation and appearances outweigh rational debate' and where the rational-critical public is transformed into a mass, manipulated by persuasive authority. According to him we have moved from a culture-debating to a culture-consuming public (Livingstone \& Lunt, 1994, p. 19).

Thus the initial question on whether the talk show programs in Albania guarantee these free public forums got an answer. Of great interest remains what happens specifically in the Albanian case?

\section{The public sphere in talk shows in Albania}

\subsection{The participation of the public}

Today, in the media Albanian reality, most of the daytime audience-participation talk shows, like 5 PM, Pasdite në Top Channel or Emisioni i pasdites but also the late-night entertaining talk shows, conceive the public in the studio only as a complementary part of the scenography and not as an interactive actor in the show. Even the communication through the new media has not been adapted the way it should have in these shows.

The talk show hosts view the involvement of the audience in the show skeptically. This logic comes from a past tradition in thinking according to which the elites do television whereas the spectators follow the show (Sulçe, 2012).

On the April 12 show, the host of the talk show Jamais Vu, Mustafa Nano, in the end of his interview with the director Mevlan Shanaj, said that: "During all the time, Mevlan Shanaj has been facing the audience. I don't know, I am trying to communicate with the direction, but I am facing the audience too and I am ending the show tonight for the first time with them..." (Jamais Vu, 2013).

Meanwhile, during the interview with the head of the Socialist Party, Edi Rama, the host of the talk show Opinion, Blendi Fevziu was surprised about the quality of the questions and concerns raised by citizens in the social networks: "I have got some very interesting questions on the Facebook page of show Opinion. A part of them are talented journalists. The citizens often make some questions that even we had not thought of" (Opinion, 2013).

Phil Donahue, the first that widely involved the audience in the live debate with the guests, says that the point of the host is to break the barrier between the public in the studio and the VIP guests, experts and politicians. This caused a revolution in the visual media. For the first time in the talk show The Phil Donahue Show, we have the movement of the public from the simple passive spectator stage to an active participant in public speaking. Donahue brought the model of the moving host that pushes the public to the famous people, while him playing the part of the moving mediator (Timberg \& Erler, 2002, pp. 6-7). Donahue dedicated all the success of his show to the public. The transmission of this show marks the foundation of the daytime audience-participation talk show genre. The same model was then followed by Oprah Winfrey, Ricky Lake, Jerry Springer or Ellen DeGeneres.

The second element has to do with the fact that in most of the Medias there are not any criteria for the selection of the public that sits in the studio. During an interview in the talk show Klubi i Mëngjesit, Adi Krasta says that the public in Albania is paid: "We find it very difficult to find a public in televisions nowadays. The public is paid. I as many colleagues of mine that are used to talk and the public reacts, find it difficult to act. It is difficult to find a public. The people were tired, they got a little money, they were old, ... That is why I have omitted the public. A colleague of mine puts on some applauds, but actually the studio is empty. At one time, the applause was mixed with some whistling. I say: No, no whistling in the studio... Today we live technically..." (The morning club, 2013)

Why is it so important the participation of the audience in a talk show?

As we noticed in the debate between Habermas and the authors of the feminist movement, the public sphere in a talk show indicates the quality of the democracy in a country.

The scholar, Ardian Vehbiu (2011) points out that "the democracy first of all requires a continuous participation of the individual, of the community and of the society in the government of the country. Democracy cannot be only free elections or only representation. At the level of public dialogue, the democracy demands a mutual exchange of information from the leader to the citizen, but also from the citizen to the leader..."

By continuing this idea, in the article entitled "How can Television 'kill' politics", the professor Artan Fuga highlights that "in Albania the politician can talk to the citizens from the screen, but it is impossible for the citizens to talk, to oppose, to argue, to support, to criticize the politician that is invited in the studio, or that is shown in the screen in a public rally transmitted in television. In this way the political communication is transformed into a communication that is called asymmetric. The politics speaks to the society, but the society cannot speak to the politics." 
That is why Fuga (2010) concludes, it has become necessary that every time that there is an important politician in the studio, there should also be an enlightened public as an active participant in the studio: When will the public in the studio come as an equal actor with the others?!

\subsection{The public sphere and the advertising space}

When speaking of the creation of a pseudo public sphere, Habermas emphasizes that there is a tendency that this sphere is transformed into an advertising space. The entire public speech is led by the advertising logic. Not only because Medias are financed by the private world, which cannot create freedom of debate without limitations. But also because according to the spirit of the advertisement, every political actor's speech tends to praise himself, as every commercial spot speaks highly of its product, whose advertisement has been paid by the financier of the commercial spot (Channel One, 2013).

This is happening more and more in Albania with talk shows, but not only.

In the late-night entertainment talk show Zonë e Lirë, the advertising space takes up a considerable part of the show, as much as it is difficult for a viewer to tell if it is about useful information or about an indirect advertisement. Thus from the monitoring made on 12 episodes for the period of April-June 2009, it was shown that the total television space reserved for topics of a cultural character was of 1288.53 minutes, bigger than the space dedicated to political issues, that was of 1253.20 minutes, even though the period under survey was the eve of the electoral campaign. Meanwhile, the total minutes dedicated to direct marketing with commercial spots, banners, posters, live promo, logos or promotional messages was of 116.46 minutes.

But in the cultural oriented topics, which took up the dominating part of the television time in the talk show Zonë $e$ Lirë, were included the singers who during this three month period have managed to promote 24 music videos, followed by the promotion of 7 books and 5 theatrical shows and movies (Luku, 2010, pp. 40-41).

Marketing experts would call this an "indirect advertising", ${ }^{1}$ efficient especially in these kinds of TV shows. Thus, in total the advertising space in the talk show Zonë e Lire it is many times bigger in time than it was actually thought and consequently more defining in this show.

If we analyze two sport talk shows, Procesi Sportiv in Top Channel and Dribbling in Vizion Plus, that are two televisions whose owners own also two numerical digital platforms, respectively Digitalb and Tring, we can say that the great economic investments are directly affecting the limitation of the debate in the studio. If we see the championships that are analyzed by the football experts and the other guests in the talk show Procesi Sportiv, are all the football championships and competitions with the exception of the English Premier League and the UEFA Cup, whose television rights are owned by the digital platform Tring (Sport's Process, 2013).

On the other hand, the talk show Dribbling (2013) in Vision Plus, analyzes only the English championship skipping the matches of other championships in the world, again because of the television rights.

When after a year of transmission, Vision Plus gave up the Formula 1 races, whose television rights were bought by Top Channel, this immediately affected the News programs and the sport talk show, which did not report or discuss any more about the races. The same thing happened with the TV programs in the television Top Channel (Monitor, 2013).

The above examples from some of the talk show in Albania prove the German researcher Habermas' thesis that the speech in this public sphere is guided by the logic of advertisements. He raises the concern that with creation of this pseudo public space the talk show host look like they are speaking on behalf of public opinion, but in fact they are speaking on behalf of their economic interests or those of the television owners.

It is not an accident that in the book "On Television" (1996), the communication sociologist, Pierre Bourdieu, emphasizes that when you undertake to analyze a TV show, you must necessarily know the power that the owners of this media represent. This, because, according to him, what mostly aggravates the public sphere of the television is precisely the economic censorship.

Under this logic falls also the policy of the guests or the deals made with the pundits in talk shows. Have you ever seen a pundit under a contract jeopardizing the economic interests of the television where he works?

Of course not!

This happens because the pundits are economically hired to be the "independent voice" of the show, for a definite

${ }^{1}$ Definition of "indirect advertising" - forms of advertising other than in newspapers and magazines, etc., for example using a product in a television show, giving a product away for free, or sponsoring events or activities. http://dictionary.cambridge.org/us/dictionary/businessenglish/indirect-advertising 
time. And everything, Bourdieu writes, happens during the big show, where the host as well as the pundit perform their roles by selling every debate as spontaneous, meanwhile everything has been prepared beforehand in details.

Such a valuable "good" as a talk show, which generates extraordinary revenues cannot be let "adrift". Arian Çani puts it beautifully when he says that the television is a great hypocrisy because it sells as spontaneous something that has been prepared in details beforehand. I would even add that the more spontaneous a conversation looks in a studio the more time it has required from the director and the host to sell it as such (Luku, EJO, 2013).

\section{Conclusions}

1. In the general outlook of Albanian televisions the four classic genres of talk shows are present. We can notice an abundance of the political talk show and absence of the night entertaining show, where the satirical programs are included.

2. The talk shows in Albania can be defined as a pseudo public space guaranteed and controlled by the media. This discussion space is taken over by a chaste of analysts and pundits that Habermas would call "the new feudal lords". In most of cases the rational debate and the diversity of thought are absent, because they are the same journalists that appear from one screen to the other.

3. In the talk shows is noticed a lack of a participating audience in the public debate. This happens for two reasons: a. First, because the hosts see skeptically the involvement of the audience in the show. This logic comes from past tradition of thinking according to which the elites are the ones who make television, whereas the spectators watch the show; $b$. The second element has to do with the fact that in most of the media there are not any selective criteria on the public sitting in the studio. Their presence is conceived as décor of the television studios, paid with money.

4. The discussion in talk shows in Albania is oriented first of all by the logic of the advertisement. This means that the hosts, the journalists or the guests do not argue at all about an issue that jeopardizes the economic interests of the television, independently of the great public interest that the issue might have. As scholar Jürgen Habermas says, with the creation of this pseudo public space the hosts look like they speak on behalf of the public opinion, but in fact they are speaking on behalf of their economic interests or of those of the owners of the television.

\section{References}

Bourdieu, P. (1996) - Belina Budini (interpreter) "About the TV and Journalism", Polis 8: Media \& Politics, UET, No.8, Winter 2009, p. 83 [Online] Available: http://revistapolis.com/polis/images/stories/revistat/polis8.pdf

Channel One (2013), An interview of Jetona Koçibelli with Prof. Aran Fuga, April 12, 2013, [Online] Available: https://www.youtube.com/watch?v=t6dJqavhfv0

Dribbling 2013, vizionplus.tv, January - April 2013, [Online] Available: https://www.youtube.com/playlist?list=PLw9N8Ugk2D1gny CJTlq61SeDdm0aPGfAs

Formula 1 TV rights were brought by Top-Channel, Monitor, February 8, 2013, [Online] Available: http://www.monitor.al/formula-1kalon -nga -vizion-plus-serish-tek-top-channel/

Fraser, N. (1990). Rethinking the Public Sphere: A Contribution to the Critique of Actually Existing Democracy, Duke University Press

Fuga, A. (2010). How can Television 'kill' politics, [Online] Available: http://www.shqiperia.com/shqip/opinionart/alD/1036/Si-mund-tavrase-televizioni-politiken

Fuga, A. (2013). Cyber- public sphere: characteristics and dynamics, June 23, 2013, [Online] Available: https://www.youtube.com/ watch?v=qwKusqLqSAA

Habermas, J., Lennox, S. \& Lennox, F. (1964). The Public Sphere: An Encyclopedia Article, JSTOR, p. 2 [Online] Available:http://www.jstor.org/discover/10.2307/487737?uid=3737464\&uid=2129\&uid=2\&uid=70\&uid=4\&sid=21102428069181

Habermas, J. (1991). The Structural Transformation of the Public Sphere, MIT Press

Jamais Vu (2013). An interview of Mustafa Nano with Mevlan Shanaj, April 12, 2013, [Online] Available: http://www.youtube.com/ watch?v=0dO8ZOIWivl

Livingstone, S. \& Lunt, P. (1994), Talk on television: audience participation and public debate, London: Routledge

Luku, E. (2010). The use of the visual space of Zonë e lirë show in public relations, Department of Journalism and Communication, Faculty of History and Philology, University of Tirana, 2010, pp. 40-41

Luku, E. (2010). "The structure of an interview in the late night entertaining show: Zonë e Lirë", Albanological Studies: Albanian Media in Transition, University of Tirana, Faculty of History and Philology, 3rd year, p. 335

Luku, E. (2013). "A theoretical approach on talk-show: Albanian case", The Science week 2013, Pristina, 2013, p. 185

Luku, E. (2013), Talk show represents the moderator, European Journalism Observatory / Albanian, June 28, 2013, [Online] Available: 
http://al.ejo-online.eu/1479/gazetaria-e-medias/talk-show-eshte-fytyra-e-moderatorit

Opinion (2013), An interview of Blendi Fevziu with Mr. Edi Rama, June 20, 2013, [Online] Available: http://www.youtube.com/watch?v =OiXCquaf-no\&noredirect=1

Sport's Process (2013), Top Channel - Albania, January - April 2013, [Online] Available: http://www.youtube.com/playlist?list $=$ PL3AD2DC69B4FA42BB

Sulçe, V. (2012). Massive communication and the individual public - a paradox or a norm?, November 5, 2012, [Online] Available: http://mediapermedian.wordpress.com/2012/11/05/hello-world/

Timberg, M. B. \& Erler, J. R. (2002) Television talk: a history of the TV Talk show, Texas: University of Texas Press

The morning club (2013), An interview of Blendi Salaj with Adi Krasta, January 29, 2013, [Online] Available: http://www.youtube.com/ watch?v=2qdGLGAuawE

Vehbiu, A. (2009). About the television debate II, Peizazhe të Fjalës, April 15, 2009, [Online] Available: http://xhaxhai.wordpress.com/ 2009/04/15/rreth-debatit-televiziv-iil

Vehbiu, A. (2011). Mute public, Peizazhe të Fjalës, February 17, 2011, [Online] Available: http://xhaxhai.wordpress.com/ 2011/02/17/publiku-memec/ 